\title{
Height of diabetic children at onset of symptoms
}

\author{
N. M. DRAYER \\ From the Department of Paediatrics, Academic Hospital, Groningen, the Netherlands
}

Drayer, N. M. (1974). Archives of Disease in Childhood, 49, 616. Height of diabetic children at onset of symptoms. At the onset of classical symptoms of diabetes mellitus, the height of the boys (expressed as SD score) was greater than the height of the girls. Also, diabetic boys were significantly taller than healthy (control) boys, but diabetic girls were not significantly taller than control girls. There was no significant difference in the midparental height, or in the age of the parents of the diabetic boys and girls.

When plotting the growth of diabetic children, it appeared that there was a difference in height of these children at the onset of symptoms compared with healthy controls, and that there was also a sex difference. The diabetic boys appeared to be relatively taller than the diabetic girls. An assessment of the initial height, as well as of the parental height and age, was therefore made.

\section{Methods}

The heights recorded for 62 diabetic children at the onset of the classical symptoms of diabetes, such as thirst and polyuria, were used. The diabetic children studied were living in the three northern provinces of the Netherlands. They were under the private care of two paediatricians, or were attending the diabetic clinic at the Academic Hospital. With the exception of 2 boys and 1 girl born in 1954 and 1957, the diabetic children were born after 1958.

In 1970 the heights and age of 639 boys and 322 girls, aged 4 to 14 years, attending school in Groningen, were recorded for matched controls. A matched control child was a child who most closely corresponded in age to the diabetic child's age.

The mean heights and SD of Dutch children, obtained from a national survey conducted in 1965 (van Wieringen, 1971), were used to calculate the SD score (Tanner et al., 1971) for both the diabetic children and their matched controls. The SD score of the height measurement is the height minus the mean height divided by the SD of the height at the relevant age. Height measurements were made by the method of Tanner, Whitehouse, and Takaishi (1966) for the matched control children aged 6 to 14 years. For the other children a modification was used in which firm traction upwards was not applied under the mastoid processes.

Received 11 February 1974.
The results are given as mean $\pm S D$. Statistical significance was assessed by the ' $t$ ' test (two-sided).

\section{Results}

The initial heights of 31 boys and 31 girls with diabetes mellitus and the heights of their matched controls were plotted on the Dutch growth charts (van Wieringen, 1971) and are shown in Fig. 1 and 2. Table I shows the mean and SD of the heights and ages of the diabetic and matched control children for

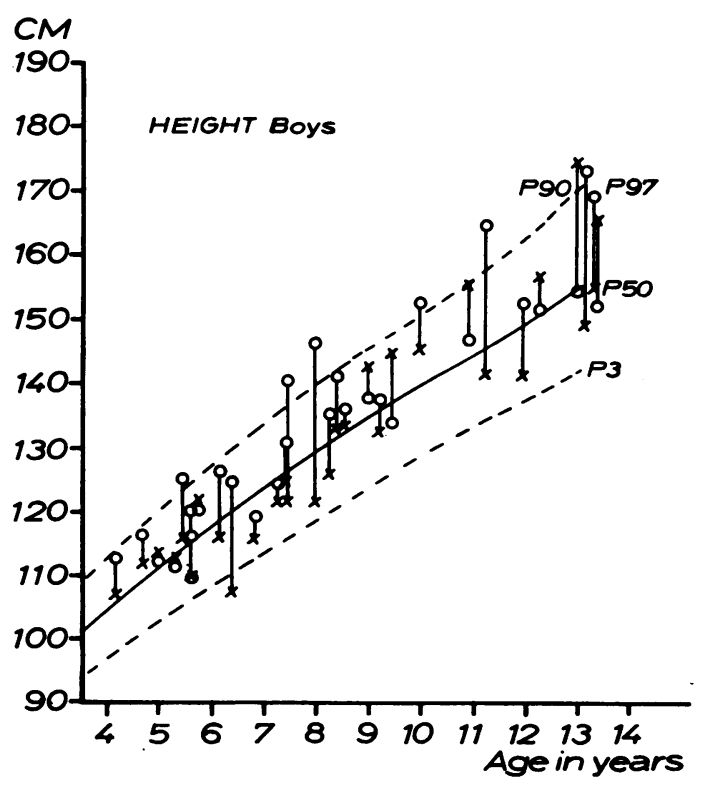

FIG. 1.-Height of boys. Diabetes mellitus 0 , matched control $x$. 
TABLE I

Height and age of diabetic children at the onset of symptoms and of matched controls

\begin{tabular}{|c|c|c|c|c|c|c|}
\hline \multirow{2}{*}{ No. } & \multirow{2}{*}{$\begin{array}{c}\text { Age group } \\
(y \mathbf{y r})\end{array}$} & \multirow{2}{*}{ Child } & \multicolumn{2}{|c|}{ Height } & \multirow{2}{*}{$\begin{array}{c}\text { Significance of } \\
\text { difference in height } \\
\text { compared with Dutch } \\
\text { children (P) }\end{array}$} & \multirow{2}{*}{$\begin{array}{c}\text { Age }(y r) \\
(\text { mean } \pm S D)\end{array}$} \\
\hline & & & $\begin{array}{c}\text { cm } \\
(\text { mean } \pm S D)\end{array}$ & $\begin{array}{c}\text { SD score } \\
(\text { mean } \pm S D)\end{array}$ & & \\
\hline $\begin{array}{r}\text { Boys } \\
31 \\
20 \\
11 \\
\text { Girls } \\
31 \\
12 \\
19\end{array}$ & $\begin{array}{l}4-14 \\
4-9 \\
9-14\end{array}$ & $\begin{array}{l}\text { Diabetic } \\
\text { Matched control } \\
\text { Diabetic } \\
\text { Matched control } \\
\text { Diabetic } \\
\text { Matched control } \\
\\
\text { Diabetic } \\
\text { Matched control } \\
\text { Diabetic } \\
\text { Matched control } \\
\text { Diabetic } \\
\text { Matched control }\end{array}$ & $\begin{array}{l}134 \cdot 9 \pm 17 \cdot 5 \\
130 \cdot 2 \pm 18 \cdot 7 \\
125 \cdot 0 \pm 11 \cdot 0 \\
118 \cdot 7 \pm 9 \cdot 6 \\
152 \cdot 9 \pm 12 \cdot 0 \\
150 \cdot 9 \pm 11 \cdot 9 \\
\\
136 \cdot 6 \pm 17 \cdot 2 \\
138 \cdot 9 \pm 16 \cdot 5 \\
118 \cdot 6 \pm 10 \cdot 3 \\
121 \cdot 6 \pm 9 \cdot 2 \\
148 \cdot 0 \pm 8 \cdot 6 \\
149 \cdot 9 \pm 8 \cdot 7\end{array}$ & $\begin{array}{r}0.79 \pm 1 \cdot 13 \\
-0.08 \pm 1 \cdot 13 \\
0.84 \pm 1 \cdot 11 \\
-0.35 \pm 0.98 \\
0.70 \pm 1 \cdot 22 \\
0.42 \pm 1.26 \\
0.11 \pm 0.95 \\
0.47 \pm 0.95 \\
0.09 \pm 1 \cdot 23 \\
0.72 \pm 0.95 \\
0.12 \pm 0.77 \\
0.31 \pm 0.95\end{array}$ & $\begin{array}{c}<0.001 \\
\text { NS } \\
0.001-0.01 \\
\text { NS } \\
\text { NS } \\
\text { NS } \\
\text { NS } \\
0.01-0.02 \\
\text { NS } \\
0.02-0.05 \\
\text { NS } \\
\text { NS }\end{array}$ & $\begin{array}{r}8 \cdot 31 \pm 2 \cdot 87 \\
8 \cdot 31 \pm 2 \cdot 86 \\
6 \cdot 51 \pm 1 \cdot 42 \\
6 \cdot 51 \pm 1 \cdot 42 \\
11 \cdot 60 \pm 1 \cdot 56 \\
11 \cdot 60 \pm 1 \cdot 57 \\
\\
9 \cdot 40 \pm 2 \cdot 80 \\
9 \cdot 39 \pm 2 \cdot 80 \\
6 \cdot 21 \pm 1 \cdot 27 \\
6 \cdot 20 \pm 1 \cdot 28 \\
11 \cdot 42 \pm 0 \cdot 99 \\
11 \cdot 41 \pm 0 \cdot 98\end{array}$ \\
\hline
\end{tabular}

NS, not significant.

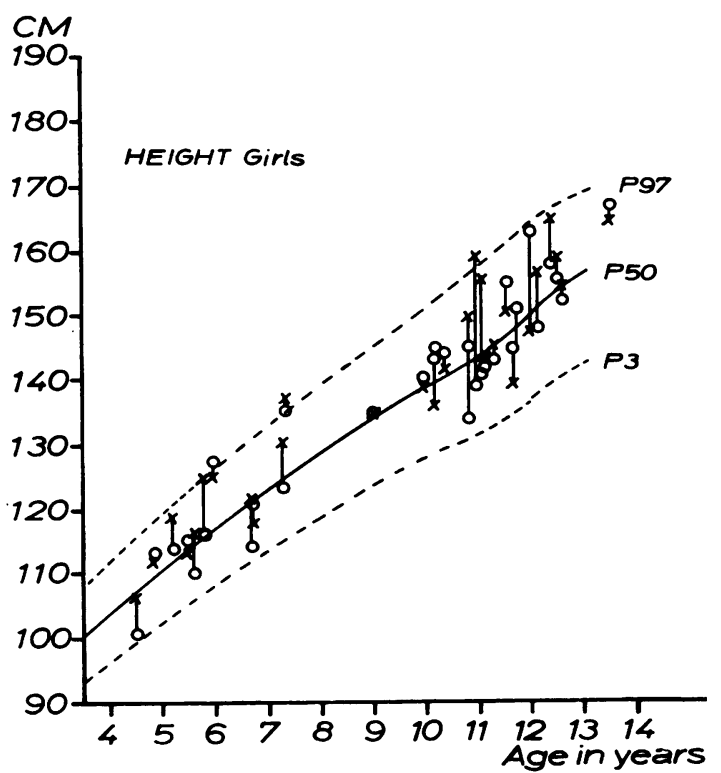

FIG. 2.-Height of girls. Diabetes mellitus $O$, matched control $x$.

the age group 4 to 14 years. The heights are expressed in $\mathrm{cm}$ as well as in SD scores. The greatest difference in age between a diabetic child and his matched control was 0.071 years.

The diabetic boys were significantly $(P<0.001)$ taller than the Dutch children, but the diabetic girls were not. Subdividing the age group of 4 to 14 years into two groups, 4 to 9 years and 9 to 14 years, showed that the diabetic boys aged 4 to 9 were taller
( $P<0.01$ ), but that the diabetic boys aged 9 to 14 were not significantly taller $(0.5<\mathrm{P}<0 \cdot 1)$ than the Dutch children.

Of the matched control children the boys did not differ significantly in height from the national survey boys, but the girls did. They were taller in the age group 4 to 14 years $(P<0.02)$ and in the subgroup aged 4 to 9 years $(P<0.05)$.

Compared to the matched controls, the diabetic boys aged 4 to 14 years were taller $(P<0 \cdot 01)$ (Table II). The boys in the subgroup of 4 to 9 years were also taller. The diabetic girls were not significantly different in height from the matched controls; however, the diabetic girls in the subgroup 4 to 9 years were shorter $(P<0 \cdot 05)$. The diabetic boys were significantly taller than the diabetic girls, but the difference in height for both subgroups 4 to 9 years and 9 to 14 years was not significant (Table III).

There was no significant difference in the midparental heights, or in the mean ages of the fathers or of the mothers of the diabetic boys and girls, as shown in Table IV. There was no striking difference in the birth order of the diabetic boys and girls, as shown in Table V.

\section{Discussion}

The difficulty in obtaining a good control series has been raised previously by other authors (Leupold, 1960; Craig, 1970). The influence of secular changes in the heights should be minimal, as nearly all diabetic children were born after 1958 and the controls were measured in 1965 (national survey controls) or in 1970 (matched controls).

The diabetic children lived in the three northern 
TABLE II

Difference in height between diabetic children at the onset of symptoms and matched controls

\begin{tabular}{|c|c|c|c|c|c|}
\hline \multirow{2}{*}{ No. } & \multirow{2}{*}{$\begin{array}{c}\text { Age groups } \\
\text { (yr) }\end{array}$} & \multicolumn{4}{|c|}{ Difference in height } \\
\hline & & $\stackrel{\mathrm{cm}}{(\mathrm{mean} \pm \mathrm{SD})}$ & $\mathbf{P}$ & $\begin{array}{c}\text { SD score } \\
(\text { mean } \pm S D)\end{array}$ & $\mathbf{P}$ \\
\hline $\begin{array}{c}\text { Boys } \\
31 \\
20 \\
11 \\
\text { Girls } \\
31 \\
12 \\
19\end{array}$ & $\begin{array}{l}4-14 \\
4-9 \\
9-14 \\
4-14 \\
4-9 \\
9-14\end{array}$ & $\begin{array}{l}+4 \cdot 7 \pm 10 \cdot 7 \\
+6 \cdot 3 \pm 7 \cdot 4 \\
+2 \cdot 0 \pm 15.0 \\
-2 \cdot 3 \pm 7.6 \\
-3 \cdot 0 \pm 4.5 \\
-1.9 \pm 9.1\end{array}$ & $\begin{array}{c}0.02-0.05 \\
0.001-0.01 \\
\text { NS } \\
\text { NS } \\
0.02-0.05 \\
\text { NS }\end{array}$ & $\begin{array}{l}+0.87 \pm 1.69 \\
+1.19 \pm 1.35 \\
+0.28 \pm 2.12 \\
-0.36 \pm 1.16 \\
-0.63 \pm 0.94 \\
-0.19 \pm 1.28\end{array}$ & $\begin{array}{c}0.001-0.01 \\
0.001-0.01 \\
\text { NS } \\
\text { NS } \\
0.02-0.05 \\
\text { NS }\end{array}$ \\
\hline
\end{tabular}

TABLE III

Difference in height between diabetic boys and girls at the onset of symptoms

\begin{tabular}{|c|c|c|c|c|}
\hline \multirow{2}{*}{$\begin{array}{l}\text { Boys } \\
\text { (no.) }\end{array}$} & \multirow{2}{*}{$\begin{array}{l}\text { Girls } \\
\text { (no.) }\end{array}$} & \multirow{2}{*}{$\begin{array}{c}\text { Age group } \\
\text { (yr) }\end{array}$} & \multicolumn{2}{|c|}{ Difference in height } \\
\hline & & & $\begin{array}{c}\text { SD score } \\
\text { (mean) }\end{array}$ & $\mathbf{P}$ \\
\hline $\begin{array}{l}31 \\
20 \\
11\end{array}$ & $\begin{array}{l}31 \\
12 \\
19\end{array}$ & $\begin{array}{l}4-14 \\
4-9 \\
9-14\end{array}$ & $\begin{array}{l}+0.68 \\
+0.75 \\
+0.58\end{array}$ & $\begin{array}{c}0.01-0.02 \\
\text { NS } \\
\text { NS }\end{array}$ \\
\hline
\end{tabular}

TABLE IV

Mean age of parents and midparental height of diabetic children

\begin{tabular}{|c|c|c|c|c|}
\hline \multirow{2}{*}{ No. } & \multicolumn{2}{|c|}{ Age (yr) } & \multicolumn{2}{|c|}{$\begin{array}{l}\text { Midparental height } \\
(\mathrm{cm})\end{array}$} \\
\hline & $\begin{array}{c}\text { Fathers } \\
(\text { mean } \pm S D)\end{array}$ & $\begin{array}{c}\text { Mothers } \\
(\text { mean } \pm S D)\end{array}$ & No. & $(\operatorname{mean} \pm S D)$ \\
\hline $\begin{array}{c}\text { Boys } \\
20 \\
\text { Girls }\end{array}$ & $33 \cdot 97 \pm 4 \cdot 95$ & $30 \cdot 33 \pm 4 \cdot 72$ & 20 & $172 \cdot 3 \pm 4 \cdot 6$ \\
\hline 20 & $32 \cdot 54 \pm 5 \cdot 53$ & $29 \cdot 41 \pm 5 \cdot 18$ & 18 & $170 \cdot 4 \pm 5 \cdot 8$ \\
\hline
\end{tabular}

TABLE V

Birth order of diabetic boys and girls

\begin{tabular}{l|c|c|c|c}
\hline Birth order & 1st & 2nd & 3rd & 4th + \\
\hline 27 boys & 8 & 6 & 4 & 9 \\
22 girls & 7 & 10 & 2 & 3 \\
\hline
\end{tabular}

provinces of the Netherlands. The mean height of children from two of these provinces is known. For the age groups 4 to 9 years and 9 to 14 years, mean height of boys was $0.9 \mathrm{~cm}$ and $1.6 \mathrm{~cm}$, respectively, and of girls $0.8 \mathrm{~cm}$ and $1.4 \mathrm{~cm}$, respectively-taller than the Dutch children from the national survey (van Wieringen, 1971). Since children from the third province are reputedly smaller than the average Dutch children and their mean heights are unknown, it was decided to use height data from the national survey and not the data from the two provinces.

In addition, another control group was obtained by measuring schoolchildren in a town situated in one of the two provinces where the children's mean heights are known. From this group a child was paired with a diabetic child purely on the basis of corresponding age. No account was taken of other factors, such as the social background.

It is difficult to interpret the finding that the matched control girls, and not the boys, were significantly taller than the national survey children. In view of this finding one can understand that at the onset of symptoms the diabetic girls, who were not different in height from the national survey children, were smaller in the age group 4 to 9 years $(P<0.05)$ than the local matched controls.

It can be concluded that diabetic boys at the onset of symptoms are taller than the national survey children as well as taller than the local matched controls. Knowing the wide range at which puberty begins, it is not surprising that a comparison of two transverse studies fails to show a significant difference in height for the small subgroup of 11 boys aged 9 to 14 years, compared with both control groups.

The published reports summarized in Table VI give conflicting reports on the initial height of diabetic children. As a group, the diabetic children's height can be taller or smaller than the control group, or be of the same height.

No study yet mentions a sex difference, though Pond (1971) noticed that both diabetic boys and girls tended to be taller than controls, and that the tendency is more marked in girls $(P<0.001)$ than in boys $(P<0 \cdot 05)$. In this study, by using SD scores, diabetic boys were found to be significantly taller 
TABLE VI

Height of diabetic children at the onset of symptoms, compared to the height of nondiabetic children

\begin{tabular}{|c|c|c|c|c|}
\hline $\begin{array}{l}\text { Location of the } \\
\text { diabetic clinic }\end{array}$ & Investigator & $\begin{array}{l}\text { Author of the relevant } \\
\text { control studies }\end{array}$ & $\begin{array}{l}\text { No. of diabetic } \\
\text { children studied }\end{array}$ & $\begin{array}{l}\text { Compared to the controls, } \\
\text { the diabetic children are }\end{array}$ \\
\hline $\begin{array}{l}\text { U.S.A. } \\
\text { Boston } \\
\text { ", } \\
\text { Iowa City } \\
\text { ", } \\
\text { New York City } \\
\text { Pittsburgh }\end{array}$ & $\begin{array}{l}\text { Spencer (1928) } \\
\text { White (1959) } \\
\text { Boyd and Nelson (1928) } \\
\text { Jackson and Kelly (1946) } \\
\text { Beal (1948) } \\
\text { Ladd (1926) } \\
\text { Fischer, Mackler, and Marks } \\
\text { (1942) } \\
\text { Danowski (1957) }\end{array}$ & $\begin{array}{l}\text { Bowditch } \\
\text { Baldwin } \\
\text { Baldwin } \\
\text { Jackson } \\
\text { Stuart and Meredith } \\
\text { Stratz } \\
\text { Burgess } \\
\text { Maresh }\end{array}$ & $\begin{array}{r}45 \\
810 \\
20 \\
86 \\
92 \\
34 \\
44 \\
4\end{array}$ & 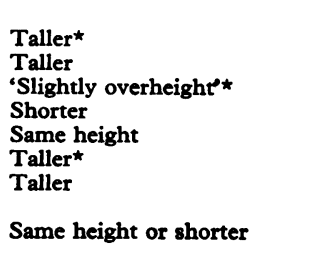 \\
\hline $\begin{array}{l}U . K . \\
\text { Birmingham } \\
\text { Glasgow } \\
\text { London }\end{array}$ & $\begin{array}{l}\text { Jivani and Rayner (1973) } \\
\text { Craig (1970) } \\
\text { Pond (1970) }\end{array}$ & $\begin{array}{l}\text { Tanner } \\
\text { Tannert } \\
\text { Tanner }\end{array}$ & $\begin{array}{r}104 \\
80 \\
101\end{array}$ & $\begin{array}{l}\text { Same height } \\
\text { Taller } \\
\text { Taller }\end{array}$ \\
\hline $\begin{array}{l}\text { Switzerland } \\
\text { Zurich } \\
\text { " }\end{array}$ & $\begin{array}{l}\text { Leupold (1960) } \\
\text { Bihrer (1970) }\end{array}$ & $\begin{array}{l}\text { Heimendinger } \\
\text { Heimendinger }\end{array}$ & $\begin{array}{r}163 \\
76\end{array}$ & $\begin{array}{l}\text { Same height } \\
\text { Same height }\end{array}$ \\
\hline $\begin{array}{l}\text { Sweden } \\
\text { Falun } \\
\text { Stockholm }\end{array}$ & $\begin{array}{l}\text { Hamne (1962) } \\
\text { Sterky (1967) }\end{array}$ & $\begin{array}{l}\text { Broman } \\
\text { (Matched control) }\end{array}$ & $\begin{array}{l}155 \\
150\end{array}$ & $\begin{array}{l}\text { Boys shorter; girls same height } \\
\text { or shorter } \\
\text { 'Boys slight increase in height' }\end{array}$ \\
\hline $\begin{array}{l}\text { Germany } \\
\text { Greifswald }\end{array}$ & Katsch (1950); Lübken (1951) & Kornfeld & 31 & Taller* \\
\hline $\begin{array}{l}\text { The Netherlands } \\
\text { Groningen }\end{array}$ & Present study & $\begin{array}{l}\text { Van Wieringen } \\
\text { (matched controls) }\end{array}$ & 62 & $\begin{array}{l}\text { Boys taller; girls same height } \\
\text { Boys taller; girls same height }\end{array}$ \\
\hline
\end{tabular}

$\star$ Diabetic boys and girls not analysed separately. †Adapted for Glasgow.

than diabetic girls. A sex difference was not found for the subgroups 4-9 years and 9-14 years, but a sex difference could conceivably have been shown to occur if both subgroups had been larger. No difference in midparental height, parental age, or in birth order was found between boys or girls.

The suggestion could be made that the diabetic condition favours the expression of the genes causing tallness, and this expression could be sex limited. It could also be that the metabolic and/or anatomic abnormalities inherent in juvenile diabetes mellitus cause either an imbalance in the neuroendocrine regulation of growth or a disturbance in the tissues responsible for growth, and in this way increase the growth in height in boys, but not in girls.

Tanner et al. (1959) suggested thyroid hormone as the only possible hormone that might be implicated in the mechanism, whereby the normal male maintains his relative growth retardation throughout the growing period. However, no indication of any sex difference in thyroid function in normal boys and girls could be found. Hypoglycaemia stimulates growth hormone release (Roth et al., 1963) and hypoglycaemic episodes are known to occur before the classical symptoms of diabetes mellitus, such as thirst and polyuria, appear (Allen, 1953). However, no difference in the occurrence of these hypoglycaemic episodes between boys and girls has been reported to the author's knowledge. Also, no sex difference has been reported in skeletal maturation in diabetic children (White, 1959).

The mechanism(s) causing the sex difference in the initial height in our diabetic children remains obscure.

I thank Drs. M. Broer and H. D. Hamming for allowing me to use data of patients in their care, and also wish to thank to Mr. L.Th. van der Weele, Computer Centre, University of Groningen, for statistical advice.

\section{REFERENCES}

Allen, O. P. (1953). Symptoms suggesting prodromal stage of diabetes mellitus. Ohio State Medical fournal, 49, 213.

Beal, C. K. (1948). Body size and growth rate of children with diabetes mellitus. Fournal of Pediatrics, 32, 170.

Bihrer, R. (1970). Erkrankungsalter und Wachstumverlauf beim jungendlichen Diabetes mellitus in der ărtzlichen Praxis. Helvetica Paediatrica Acta, 25, 312.

Boyd, J. D., and Nelson, M. V. (1928). Growth studies of children with diabetes mellitus. American fournal of Diseases of Children, 35, 753. 
Craig, J. O. (1970). Growth as a measurement of control in the management of diabetic children. Postgraduate Medical fournal, 46, (September Suppl.), 607.

Danowski, T. S. (1957). Diabetes Mellitus with Emphasis on Children and Young Adults. Williams and Wilkins, Baltimore.

Fischer, A. E., Mackler, H. S., and Marks, H. H. (1942). Long term growth of diabetic children. American fournal of Diseases of Children, 64, 413.

Hamne, B. (1962). Growth in a series of diabetic children on identical treatment with 'free' diet and insulin 1944-1960. Acta Paediatrica Scandinavica, Suppl. 135, 72.

Jackson, R. L., and Kelly, H. G. (1946). Growth of children with diabetes mellitus in relationship to level of control of the disease. fournal of Pediatrics, 29, 316.

Jivani, S. K. M., and Rayner, P. H. W. (1973). Does control influence the growth of diabetic children? Archives of Disease in Childhood, 48, 109.

Katsch, G. (1950). Über die prädiabetische Phase der Zuckerkrankheit. Deutsche Medizinische Wochenschrift, 75, 1331

Ladd, W. S. (1926). Growth in children with diabetes mellitus. American fournal of Diseases of Children, 32, 812.

Leupold, R. (1960). Erkrankungsalter und Wachstumverlauf beim jungendlichen Diabetes mellitus. Helvetica Paediatrica Acta, $15,336$.

Lübken, W. (1951). Die Manifestation des kindlichen Diabetes. Verhandlungen der Deutschen Gesellschaft für Innere Medizin, 57, 211.

Pond, H. (1970). Some aspects of growth in diabetic children. Postgraduate Medical fournal, 46, (September Suppl.), 616.

Pond, H. (1971). Diabetes mellitus. In Recent Advances in Paediatrics, 4th ed., p. 317. Ed. by D. Gairdner and D. Hull. Churchill, London.
Roth, J., Glick, S. M., Yalow, R. S., and Berson, S. A. (1963). Hypoglycaemia: a potent stimulus to secretion of growth hormone. Science, 140, 987.

Spencer, H. (1928). Diabetes mellitus in children. Studies of the height and weight of 45 patients. American fournal of Diseases of Children, 36, 502.

Sterky, G. (1967). Growth pattern in juvenile diabetes. Acta Paediatrica Scandinavica, Suppl. 177, 80.

Tanner, J. M., Prader, A., Habich, H., and Ferguson-Smith, M. A. (1959). Genes on the $\mathrm{Y}$ chromosome influencing rate of maturation in man. Lancet, 2, 141.

Tanner, J. M., Whitehouse, R. H., Hughes, P. C. R., and Vince, F. P. (1971). Effect of human growth hormone treatment for 1 to 7 years on growth of 100 children, with growth hormone deficiency, low birthweight, inherited smallness, Turner's syndrome, and other complaints. Archives of Disease in Childhood, 46, 745.

Tanner, J. M., Whitehouse, R. H., and Takaishi, M. (1966). Standards from birth to maturity for height, weight, height velocity, and weight velocity. British children, 1965. (I and II.) Archives of Disease in Childhood, 41, 454, 613.

White, P. (1959). Diabetic children, their later lives. In The Treatment of Diabetes Mellitus, 10th ed., p. 666. Ed. by E. P. Joslin, H. F. Root, P. White, and A. Marble. Lea and Febiger, Philadelphia.

Wieringen, J. C. van (1971). Seculaire groeiverschuiving. Thesis. Netherlands Institute for Preventive Medicine TNO, Leiden.

Correspondence to Dr. N. M. Drayer, Department of Paediatrics, Academic Hospital, Groningen, The Netherlands. 